\author{
ANNA SOKOŁOWSKA \\ Uniwersytet im. Adama Mickiewicza \\ $w$ Poznaniu
}

\title{
WYBRANE KONTEKSTY PRAWNE I PEDAGOGICZNE OCHRONY TWÓRCZOŚCI DZIECKA
}

\begin{abstract}
Sokołowska Anna, Wybrane konteksty prawne i pedagogiczne ochrony twórczości dziecka [Chosen Contexts of Legal and Pedagogical Protection of Child's Creativity]. Studia Edukacyjne nr 31, 2014, Poznań 2014, pp. 287-301. Adam Mickiewicz University Press. ISBN 978-83-232-2837-0. ISSN 1233-6688
\end{abstract}

This paper is an attempt to analyse a necessity of defining and extending the protection of the child's creative process. The key role of artistic instruction in the child's education and a development which calls for an appropriate framework of this process are the starting point for these considerations. This text defines artistic output as a legally protected personal interest and enumerates relevant legal regulations. It also reveals a position of the child as a creator with its specific characteristics and possible dangers arising from those characteristics. Another issue discussed here is the creative process and its components. Later on legal aspects of the child's situation in the context of creative activity are analysed with references to inter alia the UN Convention on the Rights of the Child (1989), the (Polish) Family and Guardianship Code (1964), the UN Declaration on the Rights of the Child (1959). Finally, the paper addresses objectives of arts education in the light of the issues discussed. Conclusions include an indication of certain similarities between some areas of interest in pedagogy and in law. The main conclusion comes down to a statement that in the education process we should take into consideration the a so-called creative integrity. This is a legally protected personal interest of both the adult and the child.

Key words: personal interests, artistic output, creative process/creativity, protection of creative process, creative integrity, creative process of the child, protection of child's creative process

\section{Zagadnienia ogólne}

Twórczość artystyczna jako dobro osobiste, podlegające ochronie prawnej. We współczesnym społeczeństwie obserwuje się liczne zmiany, będące na ogół konsekwencją rozwoju, oznaczającego nie tylko doskonalenie 
metod kształcenia, ale i potrzebę postępu metod ochrony prawnej procesu twórczego. W ślad za pojawieniem się nowych zjawisk lub udoskonalonych metod działania, powstaje potrzeba ujęcia ich w ramy, które wyznaczają stosowne unormowania prawne. Rozwój regulacji prawnych usankcjonował dostrzeżenie praw niematerialnych, takich jak prawa osobiste (dobra osobiste), czyli pewnych stanów rzeczy, będących szczególnie cennymi wartościami. Należy zaznaczyć, że zagwarantowana przez kodeks cywilny wolność wypowiedzi jest, obok innych stanów rzeczy, dobrem osobistym, czego konsekwencję stanowi jego prawna ochrona.

Przepis art. 23. k.c. stanowi co prawda, że dobra osobiste czlowieka, jak w szczególności zdrowie, wolność, cześć, swoboda sumienia, nazwisko lub pseudonim, wizerunek, tajemnica korespondencji, nietykalność mieszkania, twórczość naukowa, artystyczna, wynalazcza i racjonalizatorska, pozostaja pod ochrona prawa cywilnego niezależnie od ochrony przewidzianej w innych przepisach [podkreśl. - A.S.]. Jest to jednak katalog otwarty, określający tylko niektóre z tych dóbr, odgrywające dotychczas najważniejszą rolę $\mathrm{w}$ praktyce społecznej. Można zatem wskazywać także inne, nowe dobra osobiste, w tym i takie dobro, którym jest sam proces twórczy, jako szczególnie doniosły stan rzeczy.

Cechę charakterystyczną dóbr osobistych stanowi pojawiające się w sytuacji ich naruszenia negatywne odczucia emocjonalne podmiotu naruszanego dobra. Ten element występuje także w odniesieniu do naruszenia procesu twórczego. Z kolei, istotnym składnikiem procesu twórczego jest wolność wypowiedzi artystycznej, która ze swojej natury jest typem wypowiedzi. Wolność ta należy do zakresu szerokiego, podstawowego pojęcia „wolności wypowiedzi”. Wypowiedź artystyczna tym samym również stanowi dobro osobiste, czyli także jest dobrem prawnie chronionym.

Wraz z rozwojem cywilizacji pojawiła się na wspomnianym gruncie, dotyczącym ochrony samej wolności wypowiedzi, potrzeba rozróżnienia i dodatkowej ochrony zarówno procesu wypowiedzi, jak i rezultatu takiej wypowiedzi. Ochrona rezultatu twórczego dokonywana jest $\mathrm{z}$ wykorzystaniem praw autorskich, czyli praw twórcy, które zostały określone w Ustawie z 4 lutego 1994 roku o prawie autorskim i prawach pokrewnych ${ }^{1}$.

Pojawia się zatem na tym polu zbieg roszczeń ochronnych, ponieważ twórca może dochodzić ochrony swoich praw zarówno na drodze powództwa na podstawie przepisów kodeksu cywilnego, jak i Ustawy o prawach autorskich².

${ }^{1}$ DzU (Dziennik Ustaw) 1994, nr 24, poz. 83.

2 Art. 448 k.c. w związku z art. 23 i 24 k.c., oraz art. 78 Ustawy o prawie autorskim i prawach pokrewnych. 
Dziecko jako twórca. Już Edwin Ziegfield stwierdził, że wychowanie przez sztukę powinno zajmować w kształceniu ogólnym miejsce pierwszoplanowe, a nie drugorzędne, po to, żeby zapewnić współczesnemu człowiekowi

radość urzeczywistnienia samego siebie, aby mógł być dumny z tego, że jest sobą, dumny z nieupodabniania się do nikogo innego, żeby mu umożliwić życie intensywne i pełne wrażeń, a także poczucie spokoju i harmonii ${ }^{3}$.

Przede wszystkim, należy na początku zaznaczyć, że przedmioty plastyczne (artystyczne) są równie ważne w edukacji i kształtowaniu człowieka, jak inne przedmioty ogólne, np. matematyka, język ojczysty itp.

Należy sobie uświadomić, że dziecko również jest twórcą. Ponieważ na gruncie psychologii i pedagogiki ustalono, jak newralgiczny wpływ mają dorośli (wychowawcy, rodzice, bliscy) na kształtowanie dziecka, w tym jego osobowości, a co za tym idzie i jego twórczości, uzasadniona wydaje się również ochrona tego szczególnie wrażliwego obszaru twórczości - czyli twórczości dzieci, zwłaszcza tych dorastających.

Określenie twórczość odnosi w niniejszym przypadku szczególnie do procesu twórczego dziecka. Ze względu na inną jakość rezultatu twórczego, w porównaniu z twórczością osób dorosłych lub dojrzałych, a także zważywszy na wskazaną wcześniej wrażliwość i kruchość twórczości dziecięcej w porównaniu z twórczością dorosłych, uzasadnione wydaje się skupienie na ochronie dziecięcego procesu twórczego i to $\mathrm{w}$ większym nawet stopniu niż u dorosłego, co może mieć związek z postacią końcową tworzonego dzieła.

Niebezpieczeństwo nadmiernej ingerencji w twórczość dziecka. Pionier badań dziecięcych rysunków Georges-Henri Luquet podaje wiele ciekawych przykładów świadczących o tym, że jeśli tylko dziecko nie jest w procesie twórczym nadmiernie dopingowane i krytykowane przez dorosłych, to okazuje wytrwałość w swoich artystycznych poszukiwaniach. Wyraża się to $\mathrm{w}$ znacznie częściej występującym u dzieci podczas rysowania poczuciu zadowolenia $\mathrm{z}$ siebie $\mathrm{w}$ miejsce niepokoju i rozczarowania ${ }^{4}$.

W literaturze przedmiotu wskazano, że następujące we wczesnym wieku młodzieńczym odrodzenie artystyczne nie występuje u wielu dzieci, być może nawet $\mathrm{u}$ większości, jeżeli kierowanie nim $\mathrm{w}$ poprzednich okresach oddziaływało zbyt radykalnie ${ }^{5}$.

\footnotetext{
3 I. Wojnar, Estetyka i wychowanie, Warszawa 1964, s. 177-178.

${ }^{4}$ Cyt. za: A. Trojanowska, Dziecko i plastyka, Warszawa 1983, s. 25.

${ }^{5}$ H. Read, Wychowanie przez sztuke, Warszawa 1976, s. 134.
} 
Stwierdzona została także współzależność zamiaru, wyobrażenia i interpretacji twórczości plastycznej dziecka, zwłaszcza młodszego. Wskazane aktywności tworzą proces niestabilny, obejmujący nie tylko czynność tworzenia, ale i późniejszej percepcji własnego wytworu ${ }^{6}$. Z tego względu, troska o ochronę procesu twórczego dziecka rozciąga się także na ważny czas już po jego aktywności plastycznej, dotyczący komentowania przez dorosłych tego co dziecko wytworzyło.

Jest to związane $\mathrm{z}$ emocjami wynikającymi z prezentacji dzieła innym osobom, ponieważ społeczny kontekst odbioru dzieła może uruchomić ponownie emocje poznawcze oraz związane $\mathrm{z}$ "Ja" twórcy. Prezentacja efektów zakończonej pracy niezwykle silnie wzmacnia przywiązanie do dziel, urzeczywistnia efekt heureka (odkrycia) jeśli wystąpił, ponadto wzmacnia poczucie własnej wartości, ważności i dumy. Dlatego, tym samym wzmacnia motywację do dalszej pracy twórczej. Z drugiej strony, może nastąpić sytuacja odwrotna, w której nowy rezultat poznawczy zostanie odrzucony lub przyjęty obojętnie. W konsekwencji wywoła wiele odczuć negatywnych, tj. zniechęcenie, znudzenie, przesyt, poczucie mniejszej wartości, rezygnację, czy zwątpienie?

Dziecięce pomysły plastyczne mogą pojawiać się zarówno w czasie narodzin zamiaru plastycznego, jak też, co zdarza się często, już w trakcie samego procesu obrazowania. Zdaniem Georges-Henri Luqueta, drugi przypadek świadczy o płodnej nieporadności dziecka. Jednak zdaniem Anny Trojanowskiej, owa umiejętność elastycznej zmiany koncepcji obrazowej i pomysłowość skojarzeń, jakie dziecko wykazuje w procesie rysowania, świadczy raczej o sile twórczej jego wyobraźni niż o nieporadności ${ }^{8}$. Twórczość plastyczna jest przecież fragmentem całokształtu aktywności twórczej człowieka. Świadczy to przeciwko ewentualnym obawom związanym $\mathrm{z}$ koniecznością ingerencji dorosłego $\mathrm{w}$ twórczość dziecka $\mathrm{z}$ powodu jego ograniczonych zdolności. Przemawia za tym, stwierdzone w czasie przypadającym na przełom stadium pierwszych motywów i geometryzacji, spontaniczne malarstwo dziecka, któremu nauczyciel nie narzuca zbyt wielu wskazówek odnośnie użycia koloru; dziecko przejawia wówczas wyjątkową swobodę i fantazję w jego zastosowaniu9 . Największą kreatywność podczas zajęć plastycznych dziecko wykazuje, kiedy jest jedynie poinstruowane, jak

\footnotetext{
${ }^{6}$ A. Trojanowska, Dziecko i plastyka, s. 25.

${ }^{7}$ A. Tokarz, Dynamika procesu twórczego, Kraków 2005, s. 67.

${ }^{8}$ A. Trojanowska, Dziecko i plastyka, s. 26.

9 Tamże, s. 51.
} 
posługiwać się narzędziami plastycznymi, przy jednoczesnym pozostawieniu mu swobody ekspresji10.

Należy podkreślić, że osobowość ma wielki wpływ na twórczość. Z tego względu rezultat twórczości jest zależny częściowo od tego, jak została ukształtowana osobowość. Dlatego, istnieje bezpośredni wpływ przebiegu edukacji na to jakie będą rezultaty twórcze, a później nieraz i dzieła artystyczne, które z kolei oddziałują na odbiorców sztuki. Maria Montessori uważała, że rysunku nie można lub nie powinno się nauczać, ponieważ powinien być aktywnością spontaniczną, swobodną ekspresją samej istoty dziecka i jego własnych myśli11.

Nie budzi także wątpliwości podatność dziecka na styl i sposób tworzenia osób mających wpływ na jego rozwój plastyczny. Dziecko przyzwyczajone do abstrakcyjnych wzorców, np. którego rodzice malują obrazy abstrakcyjne, rozwinie u siebie styl abstrakcyjny ${ }^{12}$.

Mimo że dziecko odznacza się pewną „,świeżością” w podejściu do wielu zjawisk, może jednak ulec ona zagłuszeniu poprzez narzucanie konkretnych właściwych rozwiązań twórczych.

W literaturze sformułowano pojęcie „emocji tła”, jako dotyczących innych poza twórczością dziedzin życia i aktywności. Zauważono pozytywny wpływ emocji dodatnich na proces twórczy ze względu na prokreatywne ich działanie, w odróżnieniu od antykreatywnego działania emocji negatywnych. W szczególności odnosi się to do emocji związanych z tworzeniem własnego dzieła ${ }^{13}$. Konsekwencją jest wymóg swobodnego i życzliwego, pozbawionego elementu krytyki czy nacisku, klimatu emocjonalnego dla twórczości. Zatem, czynniki sprzyjające realizacji możliwości twórczych, to przede wszystkim świadomość bezpieczeństwa i poczucie wolności, co zostało udowodnione $\mathrm{w}$ toku przeprowadzonych badań. Stwierdzono mianowicie, że badane osoby, zarówno dorośli jak i dzieci, znalazły się w sytuacji wzbudzającej społeczny lęk, a liczba odpowiedzi oryginalnych i nowych pomysłów spadła, podobnie jak pogorszyła się jakość podanych rozwiązańn ${ }^{14}$.

${ }^{10}$ Potwierdzają to niepublikowane badania ankietowe, przeprowadzone przez A. Sokołowską wśród rodziców dzieci w wieku przedszkolno-szkolnym, dotyczące postrzegania przez nich problemu kontroli dorosłych nad procesem twórczym dziecka. Respondenci odpowiadali na zadane pytanie odnośnie przejawianej większej kreatywności dziecka, zaznaczając jedną z opcji, które określały stopień kontroli dorosłego nad procesem twórczym dziecka.

${ }^{11}$ H. Read, Wychowanie przez sztuke, s. 129.

12 Tamże, s. 139.

13 A. Tokarz, Dynamika procesu twórczego, s. 64-65.

14 Tamże, s. 71. 


\section{Proces twórczy}

Składowe procesu twórczego. Abstrahując z jednej strony od osobowości determinującej twórczość, łatwiej ująć ją wyodrębniwszy składowe procesu twórczego, które z drugiej strony warunkują powstanie dzieła, oraz jego taką a nie inną końcową formę. Na powstanie utworu składają się szkice, plany, jak również pomysły. Należy sobie uświadomić, że i one będąc elementem procesu twórczego, także mogą podlegać prawnej ochronie. Stanowią również prawnie chronione dobro intelektualne, poprzez art. 1. Ustawy o prawach autorskich, który wprost stwierdza, że przedmiotem prawa autorskiego jest każdy przejaw działalności twórczej o indywidualnym charakterze, ustalony w jakiejkolwiek postaci, niezależnie od wartości, przeznaczenia $i$ sposobu wyrażenia (utwór).

Wolność wypowiedzi twórczej implikuje proces twórczy, który z kolei stanowi wypadkową określonego stanu umysłu (stanu psychiki). Ten stan mentalny składa się z kilku wypadkowych, jak np. pomysł, plan, sfera twórcza, a także - co niezwykle ważne - spokój twórczy. Jest on bowiem szczególnie cenną wartością $\mathrm{w}$ odniesieniu do najmłodszych twórców, ze względu na już wskazaną ich podatność na sugestie.

Należy zwrócić uwagę i na to, że już sam pomysł stanowi przedmiot chroniony prawami autorskimi, nawet kiedy występuje jedynie w niezmaterializowanej formie. Natomiast po jego zrealizowaniu, nawet wstępnym, funkcjonuje już konkretny utwór, np. tekst, obraz, utwór muzyczny. Pomysł może rozwinąć się również $\mathrm{w}$ sposób niezmaterializowany, np. poprzez szczegółową wypowiedź ustną.

Ponadto, pomysł stanowi pierwszy nieodzowny element na drodze powstawania dzieła. W fazie pośredniej przybiera on przedtem formę projektu. Z pomysłu powstają więc szkice lub plany, przechodzące $\mathrm{z}$ kolei w dzieło docelowe, które wszystkie także podlegają ochronie.

$\mathrm{W}$ celu unaocznienia wartości zawartych $\mathrm{w}$ procesie twórczym, trzeba wskazać, że ich niezmaterializowane postaci, jak np. pomysł czy w dalszym etapie wypowiedź ustna, co do swej istoty, nie różnią się w swojej wartości $\mathrm{w}$ porównaniu z postaciami zmaterializowanymi, np. planu czy szkicu. Nie są one ze swej natury tak ulotne, jak elementy nie poddane materializacji. Z tych względów uzasadniona jest ochrona wspomnianej "materializacji”, a zatem pewnego konkretnego procesu, od którego zależy powstanie planów czy szkiców. Dlatego, aby proces twórczy był autonomiczny, nieskrępowany i autentyczny, potrzebna jest ochrona środowiska twórcy, zarówno $\mathrm{w}$ aspekcie materialnym, jako wyposażonej pracowni, oraz niematerialnym, czyli przede wszystkim środowiska "umysłowego", na który składają się, 
poza umiejętnościami zawodowymi, także takie stany rzeczy, jak wartości będące dobrami osobistymi, np. „spokój twórczy”.

Warto zaznaczyć, że również w samej sztuce proces twórczy przyjął postać końcową dzieła, np. w takich kierunkach jak informel (taszyzm). W tego typu malarstwie wartościowe jest przesunięcie punktu ciężkości w zjawisku tworzenia na sam jego proces i na doświadczanie materii (w przeciwieństwie do klasycznego założenia skupiającego się na efekcie końcowym). $\mathrm{Na}$ przykład, reżyser i fotograf Hans Namuth uwiecznił w 1950 roku Jacksona Pollocka z zapamiętałością komponującego „Jesienny Rytm: Numer 30”. Ta dokumentacja procesu twórczego stała się integralną częścią samego dzieła J. Pollocka. Uzmysławia to, że odtąd czas oraz działanie stanowią nowy rodzaj twórczej materii, kładąc akcent na ten niedostrzegany dotychczas element ${ }^{15}$. Okoliczność ta unaocznia tym bardziej, jak doniosły twórczo jest sam proces i że już sam w sobie może być on celem twórczym lub artystycznym. Podobnie w twórczości dziecka, liczy się przede wszystkim proces i to, jakie emocje w jego toku doświadcza.

W literaturze przedmiotu zaznacza się rolę eksploracji (zakładającej samodzielne inicjowanie przez podmiot poszukiwania informacji) jako koniecznego warunku twórczości. Ponadto, proponuje się, by aktywność twórczą pojmować za pomocą kryterium procesualnego różnorodności. A. Tokarz pokazuje, za modelem S. Szumana, że immanentną cechą poznawczej aktywności dziecka jest „konsumowanie” wzrastającej różnorodności otoczenia, co jest również niezbędną przesłanką rozwoju potencjału twórczego ${ }^{16}$. Typowe dla twórców - wrażliwość na nowość i eksploracja - zgodnie z obserwacjami, nasilają się u dzieci w wieku przedszkolnym, poprzez znaczący wzrost zachowań badawczych od 6. roku życia. Natomiast, badania starszych już dzieci wykazały wzrost selektywności eksploracji i spadek wrażliwości na nowość. Ponadto okazało się, w odniesieniu do dzieci przedszkolnych, że w porównaniu z innymi bodźcami, nowość silniej stymuluje zachowanie ${ }^{17}$. Zjawisko nowości ma stwierdzony wpływ również w odniesieniu do twórczości dorosłych. Zarówno u twórców realnych, jak i potencjalnych stwierdzono powszechnie wysoki stopień czułości na bodźce nowe i poszukiwanie nowości, a także, co istotne ze względu na poruszoną tutaj problematykę, stwierdzono przysłowiową dziecięcą „świeżość" w podejściu do traktowania powszechnie znanych obiektów ${ }^{18}$.

\footnotetext{
15 W. Włodarczyk (red.), Sztuka świata, Warszawa 1996, s. 21-23.

16 A. Tokarz, Dynamika procesu twórczego, s. 25.

17 Tamże, s. 31-32.

18 Tamże, s. 40.
} 
Nieukierunkowywanie dziecka na konieczność osiągnięcia z góry ustalonego efektu również jest wskazane, ze względu na możliwość $w$ toku swobodnej ekspresji i poszukiwań twórczych dojścia do oryginalnych i autentycznych rezultatów. Jest to związane z kolejną właściwością aktywności eksploracyjnej, czyli zabiegami manipulacyjnymi jako sposobem na przeformułowywanie problemów. Ten mentalny zabieg, wskazywany przez samych twórców oraz słynnych odkrywców, określany jest jako przyjemność „bawienia się myślami” czy "manipulowanie ideami” przy pracy nad danym problemem i polega na giętkim oraz swobodnym przekraczaniu granicy pomiędzy pojęciem a jego desygnatem.

Edukacja w kontekście wyposażenia dziecka w odpowiednie „narzędzia" ekspresji. Warto wskazać, jak przebiega proces edukacji w kontekście ekspresji plastycznej dziecka. Stanem wyjściowym jest osoba (dziecko) z pewnym zasobem wiedzy, umiejętności (w tym ekspresji twórczej) i osobistych właściwości. Pod wpływem procesu edukacji, wyżej wspomniany zasób zostaje uzupełniony o niezbędne nowe elementy, których to umiejętności dziecko samodzielnie nie byłoby w stanie nabyć. Dziecko przyswaja sobie wiedzę jemu przekazywaną, czyli następuje internalizacja tej wiedzy jako własnej. $\mathrm{W}$ rezultacie, dziecko dysponuje $\mathrm{z}$ czasem odpowiednimi narzędziami do indywidualnej ekspresji i dalszego rozwoju.

Powyższy schemat uzmysławia, że edukacja plastyczna na danym etapie zawiera się $\mathrm{w}$ dwóch zbiorach. Pierwszym jest zasób przekazywanych umiejętności, drugim natomiast - sfera osobowościowa dziecka, której dotyczą niniejsze rozważania w kontekście ochrony jego procesu twórczego.

Trzeba, aby dziecko traktowane było nie jako ktoś podrzędny, ale jako partner równorzędny. Rzecznik Praw Dziecka Marek Michalak zaznaczył na swojej stronie internetowej, podążając za myślą Janusza Korczaka, „nie ma dzieci - są ludzie". Ta interpretacja jasno wskazuje, że dziecko to przecież człowiek, tak jak dorosły, aczkolwiek dopiero nabywający przymiotów, które z czasem pozwolą mu na w pełni samodzielną ocenę rzeczywistości.

Istotnym wnioskiem jest to, że proces edukacji powinien mieć na uwadze tzw. integralność twórczą, która stanowi dobro osobiste zarówno osoby dorosłej, jak i dziecka. Dlatego jest ważne, aby szkoła nie naruszała, nawet nieświadomie, dóbr osobistych dziecka.

„Kreatywność jest cechą ludzkości, która odróżnia istotę ludzką od zwierzęcej". Pojmowana jako zjawisko w skali indywidualnej i kulturowej, pozwala przekształcić możliwości $\mathrm{w}$ rzeczywistość. Ten drugi aspekt ma miejsce wówczas, kiedy jednostka dochodzi do pewnych spostrzeżeń lub wytwarza nowe artystyczne formy, które - gdy zostaną zaakceptowane przez innych - 
stają się częścią kulturowej tradycji, są rozpoznawalne i przekazywane następnym pokoleniom.

Zauważa się, iż współcześnie metody nauczania stały się bardzo rutynowe i nakierowane na przekazanie jedynie wiedzy, bez umożliwienia uczniom doświadczania procesu, poprzez który powstają odkrycia oraz jak przekształcają one nasz świat. Ukierunkowuje się uczniów na bycie konsumentem wiedzy, zamiast zachęcać ich do uczestniczenia $w$ jej tworzeniu. Natomiast, w celu wspierania kreatywności trzeba pozwolić uczniom doświadczać procesu twórczego, dzięki któremu możliwości przekształcają się w rzeczywistość. W konsekwencji, jest to związane ze zrozumieniem otaczającego świata. Ponieważ istota ludzka jest pierwotnie fizycznie słabsza od otaczającego ją świata natury oraz drapieżników, toteż właśnie wspomniana właściwość pozwoliła mu go oswoić, a w dalszej perspektywie nad nim zapanować 19 .

Ponadto, rozwijanie kreatywności u dzieci jest niezwykle istotne $\mathrm{z}$ kilku względów. Kultura stworzona przez bieżącą generację dla niej samej może mieć później inne znaczenie dla generacji następującej. Istnieje możliwość odbierania tej kultury jako swego rodzaju więzienia w przypadku jej narzucania dzieciom przez dorosłych. $Z$ tego względu, oraz mając także na uwadze progresywne zmiany społeczne i cywilizacyjne, postuluje się umożliwianie dzieciom uczestnictwa $\mathrm{w}$ procesach tworzenia ${ }^{20}$.

Dodatkowo, działania takie wyposażają dziecko w zdolność ekspresji będącej jego indywidualnym głosem, co uprawdopodobnia prekursorski sposób myślenia i działania dziecka.

Prekursorów pojmuje się nie tylko jako poprzedników określonych chronologicznie, ale przede wszystkim z uwagi na ich funkcję odnośnie przyszłości, jak i tego co jeszcze nie istnieje ${ }^{21}$. Umożliwia to zaistnienie progresu jako integracji osoby z bieżącą epoką, w której żyje (nie w poprzedniej).

Jest to nieodzowne $\mathrm{w}$ celu uniknięcia rozdźwięku zrodzonego $\mathrm{z}$ nieadekwatności tego kim się jest i tego co się robi z czasem, w którym się znajduje. Uważa się, że jest to wynik tego, że wiele osób i dzieł nie znajduje się na swoim miejscu lub nie szuka swojego miejsca22. W historii zmian kultury jest mowa o pionierach i przestarzałych twórcach. Pierwsi dysponują zasługą otwierania, inicjowania i zdobywania nowych przestrzeni. Drudzy z kolei

${ }^{19} \mathrm{~K}$. Uichol, Creating a World of Possibilities: Indigenous and Cultural perspectives, [w:] Creativity: A Handbook for Teachers, red. A. Tan, Singapore 2007, s. xi-xii.

20 Tamże, s. xv.

${ }^{21}$ J. Schlanger, Le précurseur, [w:] Le Temps des oevres Mémoire et préfiguration, red. J. Neefs, Saint-Denis 2001, s. 14.

22 Tamże, s. 17. 
kontynuują bezwiednie dzieła odpowiednie w przeszłości, jednak niekorespondujące już, niestety, z duchem bieżącej epoki. Jest to związane z tym, że epigoni stali się nieadekwatni i retrospektywni, jednak nie ze względu na to, że to co robią miałoby być złe samo w sobie, ale ponieważ nie jest to już dłużej trafny moment ku temu. $Z$ jednej strony duch epoki jest cały czas przepełniony i gęsty, a z drugiej strony spora jego część koncentruje się na pustce - skostniałych postawach poświęcających się dla minionego społeczeństwa.

\section{Aspekty prawne}

Konstytucja Rzeczpospolitej Polskiej z 2 kwietnia 1997 roku ${ }^{23}$, będąca najważniejszym i nadrzędnym aktem prawnym, w art. 48 wyraźnie stwierdza konieczność uwzględniania wolności przekonań dziecka przy jego wychowywaniu. Wynikają z tego przepisu obowiązki spoczywające na osobach kierujących procesem twórczym dziecka, a dziecko może domagać się respektowania jego wolności w tym względzie.

Konwencja o prawach dziecka z 1989 roku. Warto zwrócić uwagę na międzynarodową regulację prawną poruszonego zagadnienia. Międzynarodowa Konwencja o prawach dziecka z 20 listopada 1989 roku²4 wyznacza jako cel kierowanie się dobrem dziecka. Stwierdzono w niej, że dziecko ma prawo do oświaty i nauki, kultury, wszechstronnego rozwoju osobowości. Dziecko jako istota ludzka wymaga poszanowania także swojej tożsamości. Ponadto, status dziecka jest oparty na założeniu szczególnej opieki, troski i ochrony prawnej ze względu na jego niedojrzałość psychiczną i fizyczną.

Ponadto, należy pamiętać, że dziecko jest samodzielnym podmiotem prawa. W prawie polskim dziecko po ukończeniu 13. roku życia może już formalnie rozpocząć samodzielną działalność gospodarczą, jednak w praktyce ma to miejsce po ukończeniu 15-16. roku życia. Dorastające dziecko może zatem samodzielnie sprzedawać swoje utwory (np. obrazy, dzieła, zwłaszcza obecnie w formie digitalnej).

Omawiana Konwencja w art. 2. stwierdza, że: Państwa-Strony w granicach swojej jurysdykcji będa respektowaty $i$ gwarantowaty prawa zawarte w niniejszej konwencji wobec każdego dziecka, bez jakiejkolwiek dyskryminacji, niezależnie od rasy, koloru skóry, ptci, języka, religii, pogladów politycznych, statusu majątkowego,

\footnotetext{
${ }^{23}$ DzU z 2001, nr 28, poz. 319.

${ }^{24} \mathrm{DzU}$ z 1991, nr 120, poz. 526.
} 
niepetnosprawności, cenzusu urodzenia lub jakiegokolwiek elementu sytuacji tego dziecka albo jego rodziców bądź opiekuna prawnego (...).

Wytyczną zawartą w Konwencji jest zabezpieczenie interesów dziecka, a należy uznać, że $\mathrm{w}$ jego interesie jest m.in. ochrona procesu twórczego. Zgodnie $\mathrm{z}$ art. 3.1. Konwencji: we wszystkich działaniach dotyczacych dzieci, podejmowanych przez publiczne lub prywatne instytucje opieki społecznej, sady, władze administracyjne lub ciata ustawodawcze, sprawa nadrzędna będzie najlepsze zabezpieczenie interesów dziecka. W kolejnym punkcie tego przepisu wskazano na konieczność działania na rzecz zapewnienia dziecku ochrony i opieki w takim stopniu, w jakim jest to niezbędne dla jego dobra. Należy przy tym wziąć pod uwagę prawa $i$ obowiąki jego rodziców, opiekunów prawnych lub innych osób prawnie za nie odpowiedzialnych, $i$ w tym celu Państwa-Strony będa podejmowaty wszelkie właściwe kroki ustawodawcze oraz administracyjne. W kolejnym przepisie art. 6.2 sygnatariusze Konwencji, a więc i Polska, mają obowiązek zapewnienia, w możliwie maksymalnym zakresie, odpowiednich warunków życia i rozwoju dziecka.

Przepisem ściśle dotyczącym swobody twórczej dziecka jest art. 13.1. Konwencji, stanowiący że: dziecko ma mieć zapewnione prawo do swobodnej wypowiedzi, a prawo to ma zawierać swobode poszukiwania, otrzymywania i przekazywania informacji oraz idei wszelkiego rodzaju, bez względu na granice, w formie ustnej, pisemnej bądź za pomoca druku, w formie artystycznej lub z wykorzystaniem każdego innego środka przekazu wedtug wyboru dziecka.

Kodeks rodzinny i opiekuńczy - Ustawa z 25 lutego 1964 roku. W Polskim Kodeksie rodzinnym i opiekuńczym, regulującym m.in. sytuację prawno-rodzinną dziecka, pojęcie wychowania składa się z dwóch elementów: wychowania w aspekcie rozwoju fizycznego i troski o rozwój duchowy.

Artykuł 96 KRO wprost stanowi, że rodzice wychowuja dziecko pozostające pod ich wtadza rodzicielska i kieruja nim. Obowiazzani sa troszczyć się o fizyczny $i$ duchowy rozwój dziecka i przygotowywać je należycie do pracy dla dobra społeczeństwa. Nacisk położony w formie obowiązku dbałości o rozwój duchowy dziecka, w tak podstawowej dla niego opiece jak rodzicielska, uzmysławia rolę i rangę kształcenia artystycznego, które niewątpliwie wpływa na sferę duchowości dziecka, a za którą odpowiedzialne są lepiej do tego przygotowane podmioty edukacyjne.

Deklaracja Praw Dziecka oraz Deklaracja Praw Człowieka. W art. 31. Deklaracji Praw Dziecka 1959 roku postanowiono, że dziecko ma prawo do nieskrępowanego uczestnictwa w życiu kulturalnym i artystycznym.

Ponadto, prawa dziecka gwarantuje również Powszechna Deklaracja Praw Człowieka z 1948 roku w art. 18., a także Europejska Konwencja 
o Ochronie Praw Człowieka i Podstawowych Wolności 1950 roku w art. 9 ust. 1. W literaturze przedmiotu określono swobodę myśli jako wolność intelektualną, możliwość swobodnego gromadzenia wiedzy i poszukiwań intelektualnych, wynalazczych oraz artystycznych. Natomiast, naruszenie tej sfery może polegać na utrudnianiu, uniemożliwianiu aktywności w omawianym zakresie, czyli na obszarze nauki, kultury i sztuki. Konsekwencją jest, że ochronie powinien podlegać proces zdobywania wiedzy, jak również ewentualnego tworzenia treści intelektualnych ${ }^{25}$.

Prawo dziecka do wolności myśli jest więc jego prawem, jednak w korzystaniu z niego dziecko nie jest całkowicie samodzielne, ponieważ znajduje się ono pod nadzorem innych osób i instytucji. Ze względu na spoczywający na rodzicach obowiązek sprawowania pieczy nad dzieckiem, omawiane prawo jest adresowane również do rodziców a także - co istotne w niniejszych rozważaniach - do organów państwowych i osób trzecich.

Należy dodać, że ochrona wolności dziecka opiera się na dwóch filarach - zabezpieczeniu przed naruszeniem (w szczególności przez usuwanie źródeł naruszenia) i usuwaniu skutków naruszenia.

Cele edukacji plastycznej. Powyższe rozważania nawiązują do problemu zadań edukacji estetycznej i artystycznej jako przedmiotu działalności wychowawczej i kształcącej, poprzez umożliwienie maksymalnego wydobycia niepowtarzalności jednostki dzięki zapewnieniu jej pełniejszych i odpowiednich warunków do rozwoju i ekspresji.

Herbert Read stwierdził, że:

(...) celem wychowania jest pobudzanie rozwoju tego, co jest indywidualne w człowieku, przy równoczesnym jednak harmonijnym włączaniu jednostki w sposób organiczny w jej środowisko, w świat grupy społecznej26.

Na tym tle omawiane zagadnienie oscyluje również wokół roli kształcenia plastycznego we współczesnym społeczeństwie, wartości wychowawczych oraz międzypokoleniowego przekazu kulturowego. Kształcenie i dokształcanie nauczycieli sztuk plastycznych powinno, poza kwestiami warsztatowymi, uwzględnić w przygotowaniu pedagogicznym element nienaruszalności procesu twórczego dziecka. Dziecko nauczone wyrażać swoją niepowtarzalną osobowość, w przyszłości jako osoba dojrzała, choć niekoniecznie jako profesjonalny twórca, będzie wzbogacać społeczeństwo.

${ }^{25}$ T. Smyczyński, Konwencja o prawach dziecka - analiza i wykładnia, Poznań 1999, s. 262.

${ }^{26}$ H. Read, Wychowanie przez sztuke, s. 15. 
Te nowe dla społeczeństwa wartości mogą dotyczyć nie tylko działalności plastycznej, ale także każdej innej działalności, której rozwój ułatwia ukształtowanie $\mathrm{w}$ toku zajęć plastycznych innych zdolności dziecka, takich jak zdolność do samorealizacji, czy kreatywność.

Wychowanie oznacza pobudzanie rozwoju, lecz rozwój - pomijając dojrzewanie fizyczne - ujawnia się tylko w ekspresji, w uzewnętrznianiu się za pośrednictwem słuchowych i wizualnych znaków i symboli27.

Warto zaznaczyć, jako podstawową kwestię, że wymagania i cele postawione edukacji kształtują w istotnym stopniu współczesnego człowieka, a ponieważ dotyczą szerokiego kręgu osób - dzieci - wpływają tym samym bezpośrednio na przyszłość społeczeństwa. Należy zauważyć również możliwość edukacji w formach wychodzących naprzeciw oczekiwaniom i problemom społecznym, ponieważ już w latach 60. ubiegłego wieku zwrócono szczególną uwagę (kongres FEA w Bazylei) na konieczność kształtowania postawy twórczej. Mianowicie, sytuacje, w jakich znajduje się obecnie człowiek wymagają nowych i oryginalnych rozwiązań, ukazując rolę, jaką sztuka może spełniać w wychowaniu. Tym bardziej że każdy człowiek jest wyposażony $\mathrm{w}$ możliwości twórcze, a nie tylko jednostki szczególnie uzdolnione artystycznie (Adolf Portmann, Victor Lowenfeld) ${ }^{28}$. Herbert Read uważał, że celem oświaty nie powinno być wytwarzanie większej liczby dzieł sztuki, lecz wychowywanie lepszych ludzi i dzięki temu lepszych społeczeństw. Uznawał to także Ernst Jaensch, twierdząc, że rozwój artystycznej aktywności u dzieci może być początkiem reformy na szerszą skalę. Jego zdaniem,

Jeżeli w jakiejś dziedzinie zostaną wyzwolone siły twórcze, wtedy musi nastąpić wyłom w stanie wszechwładnej bierności szkolnej choćby na jednym odcinku ${ }^{29}$.

Niniejsze rozważania dotyczą również kwestii roli mistrza $\mathrm{w}$ artystycznej edukacji akademickiej. Na podstawie wysuniętych wniosków, ochronę procesu twórczego należy również odnieść do studentów. Młodzież akademicka, jako dojrzalsza i bardziej świadoma w porównaniu z dzieckiem, może, ze względu na swoją pełnoletniość, szerzej korzystać z dobrodziejstwa systemu ochrony praw autorskich. Również względem osób dojrzałych należy mieć na uwadze to, by "mistrz” pełnił rolę kształtującą, a nie przytłaczającą indywidualny potencjał twórczy. Uzasadnione wydaje się ujęcie roli mistrza jako osoby obecnej w procesie twórczym, bardziej przez jego towa-

${ }^{27}$ Tamże, s. 17.

${ }^{28}$ I. Wojnar, Estetyka i wychowanie, s. 176.

${ }^{29}$ H. Read, Wychowanie przez sztuke, s. 70. 
rzyszenie i gotowość pomocy, niż przejawiającej się w nadmiernej w danej sytuacji aktywności kontrolnej tego procesu. W edukacji akademickiej kształcenie dotyczy przecież $\mathrm{w}$ pełni samodzielnych podmiotów prawnych (jako osób pełnoletnich), dysponujących pełną zdolnością do czynności prawnych. Dlatego, obecność mistrza powinna dawać poczucie oparcia jako osoba pomagająca rozwiązać ewentualny problem, nie tylko poprzez bezpośrednie wskazanie rozwiązania, ale umiejętne nakierowanie "ucznia" na tory indywidualnego dojścia do rozwiązania, będącego w pełni adekwatnym do osobowości poszukującego, a tym samym najpełniej satysfakcjonującym. O ile nauczyciel jest przede wszystkim dla dziecka autorytetem, w pewnych sferach posiadającym nawet większy wpływ niż rodzice, o tyle w nauczaniu akademickim kierowanie studentem w sposób bardziej partnerski rozwija jego indywidualne poczucie pewności siebie.

\section{Wnioski}

Najdalej posuniętą konsekwencją jest zauważenie faktu pewnego podobieństwa niektórych obszarów zainteresowania pedagogiki i prawa. W tym celu należy spojrzeć na te dwie dziedziny jako na zbiory określonych wytycznych lub norm, które owocują pewnymi sposobami zachowania lub normami zachowania.

Główna konkluzja sprowadza się do twierdzenia, że proces edukacji powinien mieć na uwadze tzw. integralność twórczą, która stanowi dobro osobiste zarówno osoby dorosłej, jak i dziecka, które podlega ochronie prawnej. Dlatego ważne jest, aby szkoła nie naruszała, nawet nieświadomie, dóbr osobistych dziecka.

\section{BIBLIOGRAFIA}

Art. 448 k.c. w związku z art. 23 i 24 k.c., oraz art. 78 Ustawy o prawie autorskim i prawach pokrewnych.

DzU (Dziennik Ustaw) z 1994, nr 24, poz. 83.

DzU z 1991, nr 120, poz. 526.

DzU z 2001, nr 28, poz. 319.

Read H., Wychowanie przez sztukę, Wydawnictwo Polskiej Akademii Nauk, Warszawa 1976.

Schlanger J., Le précurseur, [w:] Le Temps des oevres Mémoire et préfiguration, red. J. Neefs, Presses Universitaires de Vincennes, Saint-Denis 2001.

Smyczyński T., Konwencja o prawach dziecka - analiza i wykładnia, "Ars boni et aequi”, Poznań 1999. 
Tokarz A., Dynamika procesu twórczego, Wydawnictwo UJ, Kraków 2005.

Trojanowska A., Dziecko i plastyka, Wydawnictwa Szkolne i Pedagogiczne, Warszawa 1983.

Uichol K., Creating a World of Possibilities: Indigenous and Cultural perspectives, [w:] Creativity: A Handbook for Teachers, red. A. Tan, World Scientific Pub. Co. Inc., Singapore 2007. Włodarczyk W. (red.), Sztuka świata, t. X, Wydawnictwo Arkady, Warszawa 1996.

Wojnar I., Estetyka i wychowanie, Państwowe Wydawnictwo Naukowe, Warszawa 1964. 